\title{
Effective treatment of gonorrhoea in London with two oral doses of amoxycillin
}

\author{
R. R. WILLCOX \\ St. Mary's Hospital, London, and King Edward VII Hospital, Windsor
}

Amoxycillin ( $\alpha$ amino-p-hydroxybenzylpenicillin) is a new semi-synthetic penicillin with a spectrum of activity similar to ampicillin, but which has been shown to be better absorbed than ampicillin thereby producing appreciably higher serum and urine levels (Acred, Hunter, and Mizen, 1971; Croydon and Sutherland, 1971; Geddes, Williams, Kosmidis, Goodall, and Andrews, 1971). Moreover, absorption is little influenced by the presence of food.

\section{Previous work}

\section{REPORTED FINDINGS}

In an earlier paper (Willcox, 1972), a series of pilot studies were reported involving 281 male patients with acute uncomplicated gonorrhoea principally treated with single doses of 0.5 to $2 \mathrm{~g}$. amoxycillin with or without probenecid or with 1 to $2 \mathrm{~g}$. in two doses. The principal findings obtained are summarized in Table I.

These results, using either single doses of 0.5 to $2 \mathrm{~g}$. with or without $1 \mathrm{~g}$. probenecid or double doses each of 0.5 to $1 \mathrm{~g}$. at an interval of approximately $5 \mathrm{hrs}$, were almost identical to those which had been previously obtained at the same clinics using similar doses of ampicillin.

They were also similar to those obtained with single injections of 1.2 m.u. procaine penicillin by injection, but were not as good as those achieved at St. Mary's with single injections of $1.2 \mathrm{~m} . \mathrm{u}$. procaine penicillin plus $1 \mathrm{~g}$. probenecid (Cobbold, Morrison, Spitzer, and Willcox, 1970) or with single injections of $2.4 \mathrm{~m}$.u. procaine penicillin (Morrison, Cobbold, Bor, Spitzer, Foster, and Willcox, 1968).

Received for publication June 18,1973

Presented at a meeting of the M.S.S.V.D. in Brussels, in May, 1973

\section{INFERIOR RESULTS IN LONDON}

Somewhat better results with single doses of amoxycillin have been obtained in Liverpool by Alergant (1973). It has also been noted, however, that smaller doses of penicillin preparations are required in many areas outside London than are needed within the capital, doubtless because of differences in the sensitivities of the gonococcus to penicillin and possibly partly to the existence of more undisclosed early re-infections in certain groups in London. For example (Table II), using $2 \mathrm{~g}$. ampicillin plus $1 \mathrm{~g}$. probenecid in a simultaneous cooperative study, Willcox, Woodcock, Latto, John, Redmond, Parker, Rees, and Cobbold (1973) had a 10.6 per cent. failure rate based on history (denial of further sexual intercourse) in London and Windsor, while Cobbold, Rees, Parker, Woodcock, John, Latto, Redmond, and Willcox (1973) had only $2 \cdot 2$ per cent. of failures in Swansea and Port Talbot.

As it was evident that the results obtained with dosages of up to $2 \mathrm{~g}$. ampicillin were not as good in London as the best results obtained by other methods, it was decided to increase the dosage of amoxycillin to $3 \mathrm{~g}$. without probenecid, given in an initial oral dose of $2 \mathrm{~g}$. followed by $1 \mathrm{~g}$. after an interval of approximately 5 hours. At the time of the earlier paper (Willcox, 1972), 23 male patients had been so treated and there had been no failures in sixteen patients incompletely followed. It was decided therefore to extend this series to 100 male patients, and this study forms the basis of this paper.

\section{Case material}

100 male patients with acute uncomplicated gonorrhoea have been treated with $3 \mathrm{~g}$. amoxycillin in two doses, the first of $2 \mathrm{~g}$. followed by $1 \mathrm{~g}$. at an interval of 5 hours. Their average age was $27 \cdot 7$ yrs (range 17 to $63 \mathrm{yrs}$ ).

TABLE I Results obtained with a total dosage of 0.5 to $2 \mathrm{~g}$. amoxycillin in single or double doses

\begin{tabular}{|c|c|c|c|c|c|c|}
\hline \multirow[t]{2}{*}{$\begin{array}{l}\text { No. of } \\
\text { doses }\end{array}$} & \multirow[t]{2}{*}{$\begin{array}{l}\text { Dosage } \\
(\mathrm{g} .)\end{array}$} & \multirow{2}{*}{$\begin{array}{l}\text { Added } \\
\text { probenecid } \\
1 \mathrm{~g} .\end{array}$} & \multirow[t]{2}{*}{$\begin{array}{l}\text { No. } \\
\text { treated }\end{array}$} & \multirow[t]{2}{*}{$\begin{array}{l}\text { No. } \\
\text { followed }\end{array}$} & \multicolumn{2}{|c|}{$\begin{array}{l}\text { Failures based on } \\
\text { history }\end{array}$} \\
\hline & & & & & No. & Per cent. \\
\hline $\begin{array}{l}\text { One } \\
\text { One } \\
\text { Two }\end{array}$ & $\begin{array}{l}0 \cdot 5-2 \cdot 0 \\
0 \cdot 5-2 \cdot 0 \\
1 \cdot 0-2 \cdot 0\end{array}$ & $\begin{array}{l}\text { No } \\
\text { Yes } \\
\text { No }\end{array}$ & $\begin{array}{r}76 \\
132 \\
50\end{array}$ & $\begin{array}{r}67 \\
119 \\
37\end{array}$ & $\begin{array}{r}10 \\
11 \\
4\end{array}$ & $\begin{array}{r}14 \cdot 9 \\
9 \cdot 2 \\
10 \cdot 8\end{array}$ \\
\hline Total & & & 258 & 223 & 25 & $11 \cdot 2$ \\
\hline
\end{tabular}


TABLE II Results obtained with ampicillin $(2.0 \mathrm{~g}$. plus $1 \mathrm{~g}$. probenecid) in London and Wales (Cobbold and others, 1973; Willcox and others, 1973)

\begin{tabular}{|c|c|c|c|c|c|c|}
\hline \multirow[t]{2}{*}{ Series } & \multirow[t]{2}{*}{$\begin{array}{l}\text { No. } \\
\text { treated }\end{array}$} & \multirow[t]{2}{*}{$\begin{array}{l}\text { No. } \\
\text { followed }\end{array}$} & \multicolumn{2}{|c|}{ Failures based on history } & \multicolumn{2}{|c|}{$\begin{array}{l}\text { Failures based on all recurrences } \\
\text { within } 2 \text { wks }\end{array}$} \\
\hline & & & No. & Per cent. & No. & Per cent. \\
\hline
\end{tabular}

Seventy were single, 29 married, and one separated.

25 patients were Negroes (22 from the West Indies and 3 from West Africa), 56 were born in the United Kingdom, and nineteen were other immigrants ( 4 from Spain, 3 from Eire, 2 each from Cyprus, Italy and Pakistan, and one each from Algeria, Argentine, China, India, Morocco, and Saudi Arabia).

61 of the patients had had no previous history of venereal disease. The remainder had experienced 85 previous attacks of gonorrhoea, fifty of non-gonococcal urethritis, and 22 of other conditions-a total of 157 previous incidents. The 25 Negro patients accounted for 73 of these (42 of gonorrhoea, 27 of non-gonococcal urethritis, and four of other conditions), an average of 2.9 previous attacks each compared with 1.1 previous attacks for the remainder.

The duration of the urethral discharge before treatment was 1 to 3 days in 67 cases, 4 to 7 days in 29,8 to 14 days in two, 15 to 21 days in one, and over 28 days in one. Dysuria was noted by 83 patients.

The disease had been contracted from a stranger in 47 cases, from a friend in 35, from the wife in four, and from a male in fourteen. The male was a friend in seven cases and a stranger in three, and the status was unknown in four.

The apparent incubation period was 1 to 3 days in 39 cases, 4 to 7 days in 32,8 to 14 days in sixteen, 15 to 21 days in eight, 22 to 28 days in one, over 28 days in two, and unknown in two.

\section{Case management}

In all cases Neisseria gonorrhoeae were identified by a Gram-stained urethral smear which has been stated to be 99 per cent. accurate in the male (Fiumara, 1972). Nevertheless, cultures were also made in 27 cases. Serological tests for syphilis (Wassermann and VDRL) were also performed in all cases with entirely negative results throughout.

Four white capsules, each of $500 \mathrm{mg}$. amoxycillin ('Amoxil') ( $2 \mathrm{~g}$.), were swallowed by the patients in the presence of the physician and two more $(1 \mathrm{~g}$.) were given to each patient with instructions to take them $5 \mathrm{hrs}$ later. The patients were asked to return after 2 or 3 days, when a urethral smear was again made, and subsequently at 1 , and approximately 3,8 , and 12 weeks from treatment, when they were examined for urethral discharge, a smear being taken if present, and the urine inspected for haze and threads. In none of the 27 cases in which posttreatment cultures were made was a positive culture obtained when the smear was negative. It was planned to make at least one microscopical examination of the prostatic fluid during surveillance and final serum tests for syphilis at 3 months.

\section{Results}

\section{FOLLOW-UP}

By no means all patients attended at the times requested, but sufficient time has elapsed before making this report to allow all patients to have been able to attend over a period of 3 months had they obeyed instructions. The follow-up and results obtained are shown in Table III.

Of 100 patients treated, 81 were followed. The status at the last visit was satisfactory in 59, and thirteen were treated for non-gonococcal infection (eight within 3 months) and seven for re-infection (three within 3 months). There were two failures based on a history of further sexual intercourse (2.5 per cent. of those followed); one of these

TABLE III Results with $3 \mathrm{~g}$. amoxycillin in two divided doses

\begin{tabular}{|c|c|c|c|c|c|}
\hline $\begin{array}{l}\text { Duration } \\
\text { of follow-up }\end{array}$ & $\begin{array}{l}\text { No. } \\
\text { followed }\end{array}$ & $\begin{array}{l}\text { No. } \\
\text { satisfactory }\end{array}$ & $\begin{array}{l}\text { Non-gonococcal } \\
\text { infection }\end{array}$ & Re-infection & $\begin{array}{l}\text { Failures based on } \\
\text { history }\end{array}$ \\
\hline 0 & 100 & - & - & - & - \\
\hline 1-7 days & 81 & 13 & 1 & - & - \\
\hline 15-21 days & 56 & 4 & 1 & 1 & - \\
\hline $22-28$ days & 50 & 5 & 1 & - & 1 \\
\hline 1-2 mths & 43 & 9 & $5^{a}$ & 2 & - \\
\hline $2-3$ mths & 27 & 5 & - & - & - \\
\hline
\end{tabular}


failures was considerably suspect, being observed at the 28th day. No failures at all were encountered in the first week and, if only the single recurrence noted in the first 2 weeks (on the 13th day) was considered to be a failure, the failure rate was 1.2 per cent. of those followed.

\section{RESULTS ACCORDING TO ETHNIC GROUPS}

The results according to ethnic groups are shown in Table IV.

This series has proved exceptional in comparison with many other antibiotic assessments made in the same clinics under similar conditions. Not only was there a complete absence of immediate failures, but the usual higher failure rates noted among immigrants, especially Negroes, than among United Kingdomborn persons, did not occur.

\section{RESULTS RELATED TO BLOOD LEVELS}

The results obtained with the schedule $2 \mathrm{~g}$. plus $1 \mathrm{~g}$. are significantly better than those of $0.5 \mathrm{~g}$. plus $0.5 \mathrm{~g}$. or $1 \mathrm{~g}$. plus $1 \mathrm{~g}$. (Table V).

Of interest therefore are the blood levels obtained on the $2 \mathrm{~g}$. plus $1 \mathrm{~g}$. schedule (Fig. 1). According to data kindly supplied by the Beecham Research Laboratories, the assays being performed by Mr. R. Horton (Fig. 1), the average amoxycillin serum concentration in eleven subjects was $24 \cdot 6 \mu \mathrm{g}$. $/ \mathrm{ml}$. at $2 \mathrm{hrs}$ (range $17 \cdot 8$ to 35.0 ), falling to an average of 5.1 at $6 \mathrm{hrs}$ (range 1.6 to 11.8 , rising again to 11.4 at $8 \mathrm{hrs}$ (range $7 \cdot 0$ to 17.5 ), and maintaining an average of $6.9 \mu \mathrm{g} . / \mathrm{ml}$. at the 10 th hour (range $3 \cdot 2$ to $12 \cdot 2$ ).

Even allowing for the protein binding, stated to be 17 per cent. with amoxycillin, these levels are well above the MIC of test strains of the gonococcus.

Data kindly provided by Beecham Pharmaceuticals

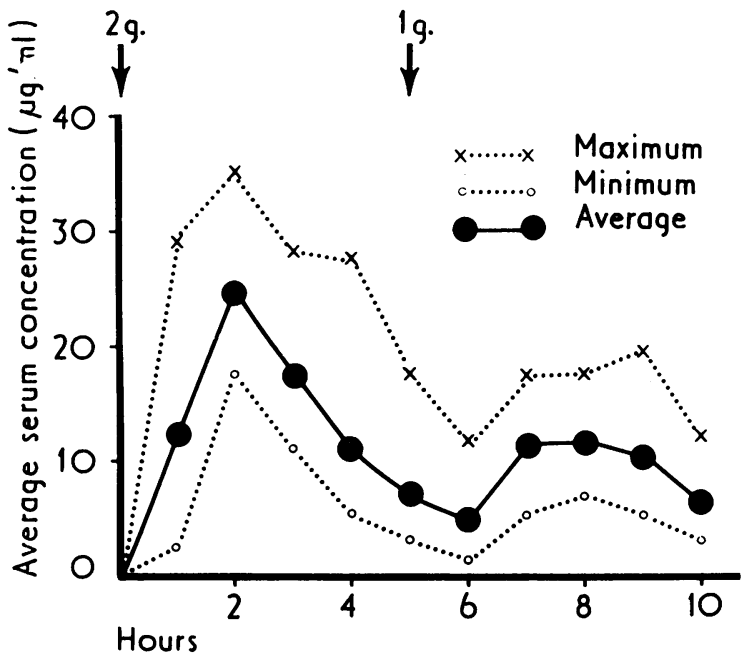

FIG. 1 Maximum, minimum, and average serum concentrations after two oral doses of amoxycillin (11 subjects)

(bacteriologist Mr. B. Slocombe) have indicated that, among 96 gonococcal strains originally obtained from the Venereal Disease Reference Laboratory at the London Hospital, the least sensitive strains to penicillin G, ampicillin, and amoxycillin had a MIC of $0.5 \mu \mathrm{g} . / \mathrm{ml}$.

This reading for amoxycillin was obtained in fifteen of 56 strains $(26.8$ per cent.) relatively insensitive to penicillin $\mathrm{G}(\mathrm{MIC} \geqslant 0.05 \mu \mathrm{g} . / \mathrm{ml}$.) and in one of forty strains $(2.5$ per cent.) sensitive to penicillin $\mathrm{G}(\mathrm{MIC}<0.05 \mu \mathrm{g} . / \mathrm{ml}$.). A similar maximum of $0.5 \mu \mathrm{g} . / \mathrm{ml}$. was found in 21 strains from Copenhagen, with only two strains reaching this

TABLE IV Results according to ethnic groups

\begin{tabular}{|c|c|c|c|c|c|c|}
\hline \multirow[t]{3}{*}{ Group } & \multirow[t]{3}{*}{ No. treated } & \multirow[t]{3}{*}{ No. followed } & \multicolumn{4}{|c|}{ Results within 3 months } \\
\hline & & & \multirow{2}{*}{$\begin{array}{l}\text { Non-gonococcal } \\
\text { infection }\end{array}$} & \multirow[t]{2}{*}{ Re-infection } & \multicolumn{2}{|c|}{ Failures based on history } \\
\hline & & & & & No. & Per cent. \\
\hline $\begin{array}{l}\text { Negro immigrants } \\
\text { Other immigrants } \\
\text { UK-born }\end{array}$ & $\begin{array}{l}25 \\
19 \\
56\end{array}$ & $\begin{array}{l}22 \\
17 \\
42\end{array}$ & $\begin{array}{l}1 \\
4 \\
3\end{array}$ & $\begin{array}{l}1 \\
1 \\
1\end{array}$ & $\frac{-}{2}$ & $\overline{\bar{Z}}$ \\
\hline
\end{tabular}

TABLE V Comparison of 3, 2, and $1 \mathrm{~g}$. amoxycillin given in two doses

\begin{tabular}{|c|c|c|c|c|c|c|}
\hline Dosage (g.) & No. treated & No. followed & \multicolumn{2}{|c|}{ Failures based on history } & \multicolumn{2}{|c|}{ All recurrences within 2 weeks } \\
\hline $\begin{array}{l}0.5+0.5 \\
1.0+1 \cdot 0 \\
2+1\end{array}$ & $\begin{array}{r}26 \\
24 \\
100\end{array}$ & $\begin{array}{l}19 \\
18 \\
81\end{array}$ & $\begin{array}{l}1 \\
3 \\
2\end{array}$ & $\begin{array}{r}5 \cdot 3 \\
16 \cdot 7 \\
2 \cdot 4\end{array}$ & $\begin{array}{l}1 \\
4 \\
1\end{array}$ & $\begin{array}{r}5 \cdot 3 \\
22 \cdot 2 \\
1 \cdot 2\end{array}$ \\
\hline
\end{tabular}


level to amoxycillin compared with ten to penicillin $\mathrm{G}$. In West London, a maximum of $1.0 \mu \mathrm{g} . / \mathrm{ml}$. has, however, been noted (Price and Fluker, 1973).

It would certainly seem from these results that a high antibiotic level for $10 \mathrm{hrs}$ represents a satisfactory time/dose relationship for the treatment of gonorrhoea in the male.

\section{Comparison with other optimal penicillin schedules}

Previously the best results have been obtained by the author and his associates in the penicillin treatment of uncomplicated gonorrhoea in males in London by means of single injections of $2.4 \mathrm{~m}$.u. aqueous procaine penicillin (Morrison and others, 1968) or with half this amount of procaine penicillin plus 1 g. probenecid (Cobbold and others, 1970). The findings of these two series are compared with those of the present study in Table VI, which indicates that the best results to date have been obtained with amoxycillin (Fig. 2).

\section{WIIIAS Failures bosed on history}

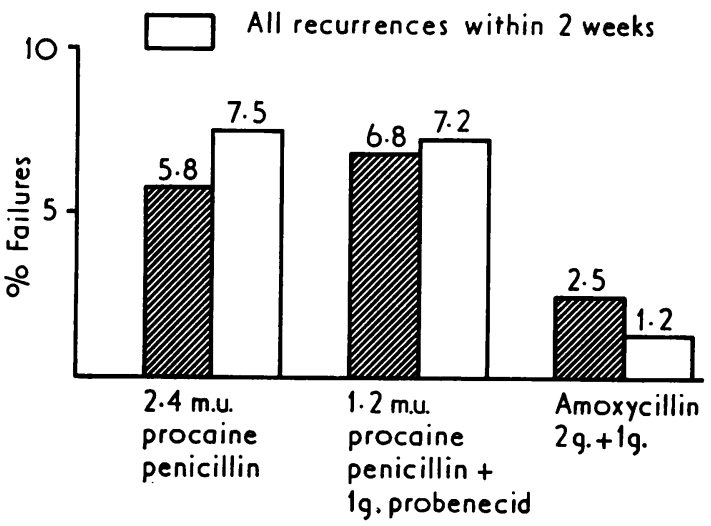

FI G. 2 Optimal schedules at St. Mary's Hospital, London, showing percentage of fallures

\section{Side-effects}

Patients with a history of penicillin sensitivity were excluded from the study. The capsules were well tolerated and no side-effects were reported.

\section{Summary and conclusions}

In continuance of previous studies of amoxycillin to determine a simple treatment of uncomplicated gonorrhoea in males which is effective in London, an optimal schedule has now been defined, using an initial oral dose of $2 \mathrm{~g}$. followed by a second dose of $1 \mathrm{~g}$. taken 5 hours later.

Of 100 males so treated, 81 were followed and, based on a denial of further sexual exposure, there were only two failures within 3 months of treatment ( 2.5 per cent. of those followed). If only the single recurrence noted within 2 weeks was counted the failure rate was 1.2 per cent.

These results have proved superior to those of previously described optimal schedules based on single injections of 2.4 m.u. aqueous procaine penicillin or half of this amount plus probenecid administered under similar conditions.

The capsules of amoxycillin were extremely well tolerated and a dosage of $3 \mathrm{~g}$. in two doses without probenecid has therefore given results which would be difficult to better in London at the present time by any other treatment.

Thanks are expressed to Beecham Laboratories Ltd. and to Messrs. Bencard, both of Brentford, Middlesex, for kindly providing the $500 \mathrm{mg}$. capsules of amoxycillin ('Amoxil') used in this study.

\section{References}

Acred, P., Hunter, P. A., and Mizen, L. (1971) Paper presented to VII International Congress of Chemotherapy, Prague

Alergant, C. D. (1973) Brit. F. vener. Dis., 49, 274

Cobbold, R. J. C., MORRISON, G. D., SPITZER, R. J., and WILlcox, R. R. (1970) Postgrad. med. f., 46, 142

—, ReEs, G. D., Parker, R. B., WOODCOCK, K., John, J., Latto, D., Redmond, A., qnd Willcox, R. R. (1973) Brit. f. vener. Dis., 49, 268

Croydon, E. A. P., and Sutherland, R. (1971) Paper presented to VII International Congress of Chemotherapy, Prague

Fiumara, N. J. (1972) Med. Clin. N. Amer., 56, 1105

GedDes, A. M., Williams, J. D., Kosmidis, J., Goodall, J. A. D., and ANDRews, J. (1971) Paper presented to VII International Congress of Chemotherapy, Prague

TABLE VI Results of present study compared with previous optimal schedules

\begin{tabular}{|c|c|c|c|c|c|c|c|}
\hline \multirow[t]{2}{*}{ Schedule } & \multirow[t]{2}{*}{$\begin{array}{l}\text { No. of } \\
\text { doses }\end{array}$} & \multirow[t]{2}{*}{$\begin{array}{l}\text { No. } \\
\text { treated }\end{array}$} & \multirow[t]{2}{*}{$\begin{array}{l}\text { No. } \\
\text { followed }\end{array}$} & \multicolumn{2}{|c|}{$\begin{array}{l}\text { Failures based on } \\
\text { history }\end{array}$} & \multicolumn{2}{|c|}{$\begin{array}{l}\text { All recurrences within } \\
2 \text { weeks }\end{array}$} \\
\hline & & & & No. & Per cent. & No. & Per cent. \\
\hline $\begin{array}{l}2 \cdot 4 \text { m.u. procaine } \\
\text { penicillin }\end{array}$ & One & 280 & 240 & 14 & $5 \cdot 8$ & 18 & $7 \cdot 5$ \\
\hline $\begin{array}{l}1.2 \text { m.u. procaine penicillin } \\
\text { plus } 1 \mathrm{~g} \text {. probenecid }\end{array}$ & One & 307 & 264 & 18 & $6 \cdot 8$ & 19 & $7 \cdot 2$ \\
\hline Amoxycillin $3 \mathrm{~g}$ & Two & 100 & 81 & 2 & $2 \cdot 5$ & 1 & $1 \cdot 2$ \\
\hline
\end{tabular}


Morrison, G. D., Cobbold, R. J. C., Bor, S., SPITzER, R. J., FosteR, D. N., and Willcox, R. R. (1968) Brit. F. vener. Dis., 44, 319

Price, J., and FlukrR, J. L. (1973) Paper presented to The Medical Society for the Study of Venereal Diseases, Brussels

Willcox, R. R. (1972) Brit. f. vener. Dis., 48, 504

, WOODCOCK, K. R., LATTO, D., JohN, J., REDMOND, A., Parker, R. B., Rees, G. D., and Cobbold, R. J. C. (1973) Brit. F. vener. Dis., 49, 263

Efficacité à Londres du traitement de la gonococcie par deux doses orales d'amoxycilline

\section{SOMMAIRE}

Poursuivant les études précédentes sur l'amoxycilline pour mettre au point un traitement simple de la gonococcie masculine non compliquée, efficace à Londres, un schéma optimal a maintenant été établi, prescrivant une dose orale initiale de $2 \mathrm{~g}$ suivis par une deuxième dose donnée 5 heures après.

Parmi les 100 hommes ainsi traités, 81 furent suivis et, pour ceux qui niaient un contact sexuel ultérieur, il y eut seulement deux échecs au cours des 3 mois suivant le traitement (2,5 pour cent des cas suivis). Si l'on tient compte uniquement d'une seule rechute survenant au cours des 2 premières semaines, le taux d'échec fut de 1,2 pour cent.

Ces résultats sont donc supérieurs à ceux des schémas optimaux antérieurement décrits faisant appel à une injection unique de $2,4 \mathrm{~m} . \mathrm{u}$. de pénicilline procaine aqueuse ou à la moitié de cette deos plus probénécide, schémas administrés dans des conditions similaires.

Les capsules d'amoxycilline furent très bien tolérées et une posologie de $3 \mathrm{~g}$ en deux doses sans probénécide a donc donné des résultats tels qu'il serait difficile d'obtenir meilleurs à Londres actuellement par tout autre traitement. 